\title{
UNIVERSITYOF
}

FORWARD

THINKING

WESTMINSTER用

WestminsterResearch

http://www.westminster.ac.uk/westminsterresearch

\section{Biocatalytic electrode improvement strategies in microbial fuel cell systems}

Breheny, M., Bowman, K., Farahmand, N., Gomaa, O., Keshavarz, T. and Kyazze, G.

This is the peer reviewed version of the following article: Breheny, M., Bowman, K., Farahmand, N., Gomaa, O., Keshavarz, T. and Kyazze, G. (2018) Biocatalytic electrode improvement strategies in microbial fuel cell systems. Journal of Chemical Technology and Biotechnology, DOI: 10.1002/jctb.5916, which has been published in final form at: https://dx.doi.org/10.1002/jctb.5916.

This article may be used for non-commercial purposes in accordance with Wiley Terms and Conditions for Self-Archiving.

The WestminsterResearch online digital archive at the University of Westminster aims to make the research output of the University available to a wider audience. Copyright and Moral Rights remain with the authors and/or copyright owners.

Whilst further distribution of specific materials from within this archive is forbidden, you may freely distribute the URL of WestminsterResearch: ((http://westminsterresearch.wmin.ac.uk/)).

In case of abuse or copyright appearing without permission e-mail repository@westminster.ac.uk 


\title{
Biocatalytic electrode improvement strategies in microbial fuel cell
}

\section{systems}

\author{
Mark Breheny ${ }^{1}$, Kyle Bowman ${ }^{1}$, Nasim Farahmand ${ }^{1}$, Ola Gomaa ${ }^{2}$, Taj Keshavarz ${ }^{1}$ and Godfrey \\ Kyazze $^{1}$
}

1 School of Life Sciences, University of Westminster, London W1W 6UW, United Kingdom

2 Microbiology Department, National Centre for Radiation Research and Technology (NCRRT), Egyptian Atomic Energy Authority (EAEA), Cairo, Egypt

Correspondence to: Mark Breheny, School of Life Sciences, University of Westminster, London W1W 6UW, United Kingdom. Email: m.breheny1@westminster.ac.uk

\section{ABSTRACT}

Microbial fuel cells (MFCs) produce electricity as a result of the microbial metabolism of organic substrates, hence they represent a sustainable approach for energy production and waste treatment. If the technology is to be implemented in industry, low cost and sustainable bioelectrodes must be developed to increase power output, increase waste treatment capacity, and Jimprove service intervals. Although the current application of abiotic electrode catalysts, such as platinum and electrode binders such as Nafion leads to greater MFC performance, their use cost prohibitive. Novel bioelectrodes which use cost effective and sustainable materials are being developed. These electrodes are developed with the intention to reduce start-up time, reduce costs, extend life-span and improve core MFC performance metrics (ie. power density, current density, chemical oxygen demand (COD) reduction and Coulombic efficiency (CE)). Comparison of different MFC systems is not an easy task. This is due to variations in MFC design, construction, operation, and different inocula (in the case of mixed-culture MFCs). This high intra system variability should be

This article has been accepted for publication and undergone full peer review but has not been through the copyediting, typesetting, pagination and proofreading process, which may lead to differences between this version and the Version of Record. Please cite this article as doi: $10.1002 /$ jctb.5916

This article is protected by copyright. All rights reserved. 
considered when assessing MFC data, operation and performance. In this review article, we examine the major issues surrounding bioanode and biocathode improvement in different MFC systems, with the ultimate goal of streamlining and standardising improvement processes.

\section{ABBREVIATIONS}

AHL

$\mathrm{N}$-acyl homoserine lactone

CE

coulombic efficiency

CLSM

confocal laser scanning microscopy

COD

chemical oxygen demand

DCMFC

dual chamber MFC

$E A B$

electroactive biofilm

EET

extracellular electron transfer

MFC

microbial fuel cell

minimal salt media

MWCNT multi-walled carbon nanotube

ORR

oxygen reduction reaction

PEM

proton exchange membrane

QSM

quorum sensing molecule

SCMFC

single chamber microbial fuel cell

SEM

scanning electron microscopy

This article is protected by copyright. All rights reserved. 


\section{INTRODUCTION}

MFCs can produce electricity by exploiting the capability of exoelectrogenic bacteria to transfer electrons, via the metabolism of organic substrates to an electrode. MFCs represent a promising approach for sustainable energy production (Figure 1). ${ }^{1}$ MFCs have been reported to be tolerant of a wide range of carbon feed stocks in wastewater. ${ }^{2}$

There are three main mechanisms of extracellular electron transfer (EET). The first, direct electron transfer, involves electrons which are transferred directly from the outer cell membrane to the electrode. ${ }^{3,4}$ The second, chemically mediated electron transfer, describes where electrons are transferred between the cell and the electrode via soluble redox shuttles such as flavins. ${ }^{5}$ Finally electron transfer is conducted by biological nanowires. ${ }^{6}$ The importance of the interaction between exoelectrogenic bacteria and the electrode cannot be understated. MFCs rely on the efficient transfer of electrons from anodic exoelectrogens to the cathode, where electrons participate in reduction reactions.

In this review we explore avenues for improvement in both the anode and the cathode, with an emphasis on biological catalysis. These are explored within the context of the current challenges facing the field (Table 1.). In our opinion, with continued research and development, MFC system performance can be improved, enabling this technology to transcend from a research curiosity to application at industrial scale.

\section{BIOANODE CONSIDERATIONS}

A bioanode is defined as an anode with a biological component. At the bioanode, exoelectrogenic bacteria donate electrons to the electrode surface, which functions as the temporary terminal

This article is protected by copyright. All rights reserved. 
electron acceptor under anaerobic conditions. ${ }^{7}$ In MFCs, anodes are associated with an adherent mass of cells known as the electroactive biofilm $(E A B),{ }^{8}$ and are thus not usually given the 'bio' designation. There are many factors, which can influence anodic electron uptake efficiency, some of which are discussed within this review. Improvement of the bioanode is an essential aspect for practical MFC system operation.

\section{Bioanode material}

The choice of bioanode material is an important consideration in MFC development. The material should be conductive and should not be corrosive. The material must also facilitate the attachment of microorganisms. A variety of anode materials have been used in different studies. Metal-based electrodes, such as stainless steel have been used, ${ }^{9}$ but the most commonly used are carbon-based, including carbon cloth, ${ }^{10}$ carbon paper, ${ }^{11}$ carbon brush, ${ }^{12}$ carbon felt, ${ }^{13}$ graphite rod $^{14}$ and graphite plate. ${ }^{15}$ Many different arrangements of carbon-based electrodes in terms of their shape, ${ }^{16}$ size ${ }^{17}$ and physical location ${ }^{18}$ have been reported.

\section{Novel anode preparation techniques}

The scope for novel directions in anodic surface development is shown by Zhang, et al., ${ }^{19}$ wherein the common preparation methods of anodes were examined. Of note was their use of a multiwalled carbon nanotube (MWCNT) and of vacuum filtration, as improved methods of anode preparation. The MWCNT functioned as a solid conductive matrix (or "nanowire") for the biofilm. Four different anodic variations were prepared and compared in otherwise identical MFC systems; (i) Control - the activated carbon anode, inoculated once placed in the MFC with $4 \% \mathrm{v} / \mathrm{v}$ bacterial solution, (ii) Vacuum filtered MWCNT only - the activated carbon anode, had MWCNT vacuum filtered through it and once in the MFC was inoculated with $4 \% \mathrm{v} / \mathrm{v}$ bacterial solution, (iii) Vacuum

This article is protected by copyright. All rights reserved. 
filtered bacteria only - the activated carbon anode had bacterial solution filtered through it prior to insertion in the MFC, and (iv) Vacuum filtered MWCNT/bacterial hybrid - the activated carbon anode had MWCNT and bacterial solution vacuum filtered through it prior to insertion into the MFC. The 'start-up' time with the vacuum filtered MWCNT/bacterial hybrid was reduced by $53.8 \%$ compared to the control. However, in the "vacuum filtered bacteria only" system, the anode showed a prolonged start-up time, compared to control. These findings can be corresponded to the SEM analyses, which show the vacuum filtered MWCNT/bacterial hybrid with thick layers (40 $\mu \mathrm{m})$, but with many $\mu \mathrm{m}$-scale channels, which could accelerate the substrate transfer rate inside the biofilm. The built-in MWCNT nanowire enhanced both the electron transfer and the substrate diffusion property of the biofilm. However, in the case of the vacuum filtered bacteria only anode, SEM analysis displayed the entire electrode surface almost uniformly coated with a layer of approximately $10 \mu \mathrm{m}$ in thickness. This seemingly 'overloaded' the anode with bacteria, likely contributing to a lack of substrate accessibility and thus a reduced substrate transfer rate.

\section{Anodic inoculum}

Depending on the desired application of the MFC system, different inoculum types can be deemed the most appropriate. Herein different inocula types are discussed.

\section{Pure culture}

Pure culture MFCs are those which contain only a single exoelectrogenic species. Pure culture MFCs are often used when conducting laboratory testing to investigate the impact of specific factors, to control the variation introduced by having more than one microorganism present. ${ }^{20}$ Pure cultures tend to have a higher medium specificity and are at an increased risk of contamination with undesired microbial growth, ${ }^{21,22}$ compared to mixed cultures.

This article is protected by copyright. All rights reserved. 
Studies using pure cultures of exoelectrogenic extremophiles that operate under extreme conditions, have shown the capability of extremophiles to function in MFC conditions where other exoelectrogens would not survive. ${ }^{23,24}$ Monzon, et al. reported on improvements to an MFC system which used the extremophile Halanaerobium praevalens on the anode to treat high-salinity wastewater, which is difficult to treat using conventional technologies. ${ }^{25}$ The findings of this study are discussed in the section entitled "Quorum sensing". Abrevaya et al. investigated two archaea microorganisms, namely; Haloferax volcanii and Natrialba magadii, used as biocatalysts in the anode of an MFC system. ${ }^{26}$ Both extremophiles are able to grow at high salt concentrations. In the case of $H$. volcanii, when natural red was used as the redox mediator, the maximum power density recorded increased from $11.87 \mu \mathrm{W} \mathrm{cm}{ }^{-2}$ to $50.98 \mu \mathrm{W} \mathrm{cm}{ }^{-2} . N$. magadii showed a smaller proportional increase in power density upon the addition of natural red, from $4.57 \mu \mathrm{W} \mathrm{cm}^{-2}$ to $5.39 \mu \mathrm{W} \mathrm{cm}$.

\section{Mixed culture}

Defined mixed cultures consist of two or more different known microorganism species, used together in the same MFC. ${ }^{27}$ Hassan, et al.'s study compared the performance of an MFC system containing pure cultures of (i) Nocardiopsis sp. KNU, (ii) Streptomyces enissocaesilis KNU, and (iii) a mixed-culture of both. ${ }^{28}$ The single cultures produced maximum power density values of $162 \mathrm{~mW} \mathrm{~m}$ ${ }^{2}$ and $145 \mathrm{~mW} \mathrm{~m}^{-2}$ respectively, whilst the coculture produced the highest value of $188 \mathrm{~mW} \mathrm{~m}^{-2}$. Ren, et al.'s study into the performance of a Clostridium cellulolyticum and Geobacter sulfurreducens defined mixed culture MFC system, showed that whilst the coculture produced a maximum power density of $143 \mathrm{~mW} \mathrm{~m}^{-2}$, neither pure culture alone produced electricity using cellulose as a substrate. ${ }^{29}$ C. cellulolyticum is a non-exoelectrogen, whereas G. sulfurreducens is an exoelectrogen. G. sulfurreducens is incapable of cellulose metabolism and when fed cellulose as a substrate, cannot break it down to produce power. When the two are used in combination, C. cellulolyticum 
metabolises the cellulose such that it can be used by G. sulfurreducens, which goes on to produce power as a result of EET. This demonstrates that mixed cultures can access and use substrates that would be inaccessible to pure cultures. Also in the study, using scanning electron microscopy (SEM), the coculture's $E A B$ was compared with the $E A B$ of an undefined mixed culture from activated sludge. The coculture's EAB formed patchy but tight microcolony structures, whereas the undefined mixed culture formed a more uniform EAB. Fungal-bacterial cocultures have been less studied in MFC systems. Fernandez de Bios et al. used a defined culture of the fungus Trametes versicolor and the exoelectrogen Shewanella oneidensis in the anode chamber of an MFC so that the bacterium would use the networks of the fungus to transport the electrons to the anode. ${ }^{30}$ Their system, which was linked to azo dye degradation in the cathode chamber, generated stable electricity, (stable voltage of approximately $1000 \mathrm{mV}$ across $1000 \Omega$ resistance) which was enhanced when electroFenton reactions occurred in the cathode chamber.

An undefined mixed culture is where a sample from a natural or industrial setting is extracted, and used in an MFC, ${ }^{31}$ so the microbial make-up is undefined prior to use. The source of inoculum is of great importance, as it is from this source that the potential microbiological diversity comes. There are three main groups of inoculum sources; sediments and soils, wastewaters and extreme environments. ${ }^{32}$ In terms of achieving the highest degree of exoelectrogenic diversity, soil has been reported as the best inoculum source. ${ }^{32}$ Wastewater treatment is one of the most researched aspects in MFC technology $y^{33,34}$ and in many studies, wastewater is used as the inoculum source..$^{35-37}$ However wastewater is not a good source of exoelectrogenic diversity, as it does not contain insoluble minerals nor metals, which can serve as external electron acceptors. ${ }^{32}$ In their absence, microorganisms are unlikely to be under pressure to develop the ability to carry out EET, which is the defining feature of exoelectrogens. Undefined mixed culture has been a popular inoculum source in MFC studies to date. This greater diversity of exoelectrogens has a higher resistance against process disturbances, a lack of sterilisation requirements and a greater adaptive capacity, ${ }^{38}$ making it the

This article is protected by copyright. All rights reserved. 
most pragmatic inoculum source for industrial applications. A method to increase exoelectrogenic diversity is to mix multiple inocula together, prior to or during enrichment in an MFC. ${ }^{32}$ Some of the disadvantages of using undefined mixed culture-based MFCs are the potential for substrate conversion to methane, ${ }^{39}$ the potential for the production of sulphides, e.g. $\mathrm{H}_{2} \mathrm{~S}$, which can be toxic to exoelectrogens and run to run variability as microorganisms may vary for each run. ${ }^{40}$

\section{Anolyte composition and characteristics}

There is currently no agreement on the ideal growth medium for anodic enrichment and operation of undefined mixed-culture MFCs. This is due to the inherent variability of different undefined mixed-culture inocula. Pure cultures however display high substrate specificity, ${ }^{38}$ making the development of a standardised growth medium much more attainable. The inherent variation and contamination risk that goes with wastewater treatment makes the use of pure culture difficult in that application. It has been shown that otherwise identical MFCs with different media or different $\mathrm{pH}$ values, give rise to different anodic microbial community make-ups and systemic process performances. ${ }^{41,42}$

\section{Medium type}

Defined media are commonly used when conducting laboratory testing into the impact of specific factors on MFCs, in order to reduce variables..$^{43} \mathrm{~A}$ standard defined growth medium, often referred to as 'synthetic wastewater', reported extensively in the literature, normally consists of minimal salt media (MSM), supplemented with trace elements, vitamin mix, a carbon source, and a protein source. $^{44-47}$

This article is protected by copyright. All rights reserved. 
In many MFC industrial applications, including wastewater treatment, media are undefined or 'approximated'. Pandey, et al. reported that among the many different wastewater sources, distillery industry and agriculture processing wastewaters, in particular have better efficiency because of the presence of methanogenic inhibitors and electron transfer mediators such as lignin. ${ }^{48}$

The medium used during the MFC enrichment process can be different to the eventual wastewater, which the MFC is being designed to treat. The enrichment medium can be defined medium which, through improvement, selects for the growth of the most advantageous exoelectrogenic species for the given purpose. Once the bioanode is enriched, the MFC can be exposed to wastewater and treatment may commence. The advantage of using a different enrichment medium over starting MFC operation with wastewater is that it may reduce 'start-up' time by allowing the biofilm to develop at a faster rate. There is no standardised definition of 'start-up' time across MFC studies, however it can be understood to describe the period of time before an MFC reaches its stable operating voltage. This voltage varies between MFC designs and studies, presenting another difficulty in intra-study comparisons. In the case of fed-batch culture MFCs, this is often defined as the return to the same operational voltage upon repeated fed-batch cycles.

\section{pH conditions}

Microbial bioanodic activity is greatest at an optimum $\mathrm{pH}$, which varies between studies. ${ }^{49,50}$ Therefore, consideration of initial $\mathrm{pH}$ and change in $\mathrm{pH}$ during operation are among important factors in MFC operation. ${ }^{51,42} \mathrm{pH}$ is a factor which influences both single and dual chambered MFCs. ${ }^{52,53}$

This article is protected by copyright. All rights reserved. 
In a single-chamber MFC (SCMFC) (Figure 2), both the anode and cathode are immersed in the same solution (normally fully immersed in the case of the anode and partially immersed in the case of the cathode), and hence are both subjected to similar $\mathrm{pH}$ conditions. He et al. found that an undefined mixed culture air-cathode SCMFC can tolerate an electrolyte $\mathrm{pH}$ as high as 10 with optimal conditions between $\mathrm{pH} 8$ and $10 .^{54}$

In the case of dual-chamber MFCs (DCMFC) (Figure 3), Cheng, et al. reported the emergence of a pH gradient between the anodic and cathodic chambers, across the proton exchange membrane (PEM), as being detrimental to MFC system performance, by putting an electrochemical/thermodynamic constraint on MFC performance. ${ }^{55}$ They cite this as one of the major bottlenecks in MFC technology. Jadhav and Ghangrekar however, found in their study a greater pH difference between the anode and the cathode favoured higher current and voltage. ${ }^{56}$ They report a $\mathrm{pH}$ difference of 2 units between the chambers produced a maximum power density of $17.1 \mathrm{~mW} \mathrm{~m}{ }^{-2}$, whereas no $\mathrm{pH}$ difference produced a maximum power density of $15.1 \mathrm{~mW} \mathrm{~m}^{-2}$. They state that a higher proton concentration gradient across the PEM increases the proton flux rate through the PEM. The use of $\mathrm{pH}$ buffers to sustain constant $\mathrm{pH}$ in MFC systems is commonplace in research. ${ }^{57}$ An ideal buffer should be able to maintain constant $\mathrm{pH}$ without interfering with chemical reactions or microbial physiology, whilst facilitating proton transport to the cathode for higher power densities and increased electrolyte conductivity. ${ }^{58}$ However in industrial scale wastewater treatment, the use of a buffer is viewed as impractical, principally due to cost. ${ }^{59}$

\section{Targeted biocatalytic and novel treatments}

To achieve improved core MFC performance metrics (power density, COD reduction, etc.), targeted treatments can be adopted. Herein, three such treatments are discussed.

This article is protected by copyright. All rights reserved. 


\section{Methanogenic inhibition}

A recurring theme in undefined mixed-culture MFCs is the proliferation of non-exoelectrogenic methanogens in the anodic chamber. ${ }^{60-62}$ In the anodic chamber, methanogens compete with exoelectrogens for free electrons, space on the anode and protons released by exoelectrogens for methanogenesis, thus reducing the CE of the MFC. ${ }^{63-65}$ The production of methane as a result of methanogenic activity in an MFC system makes their presence highly problematic in a technology that is hoped to provide an environmentally friendly energy source. ${ }^{66}$ A variety of methods for methanogen suppression have been reported (Table 2).

Heat as a method of inoculum pre-treatment has been described by Vamshi Krishna and Venkata Mohan, ${ }^{65}$ wherein mixed-culture sludge was treated for one hour at $80^{\circ} \mathrm{C}$, followed by 24 -hour anaerobic incubation at room temperature, before seeding in the MFC. Compared to the control mixed-culture sludge, power density increased from $92.08 \mathrm{~mW} \mathrm{~m}^{-2}$ to $128.26 \mathrm{~mW} \mathrm{~m}^{-2}$, whilst CE increased from $2.89 \%$ to $4.75 \%$. A clear shift in bioanode microbial community make-up was also observed. In treated MFCs compared to controls, a huge proportional decrease in Firmicutes species and a total demise of Caldiserica species was observed, along with a huge proportional increase in proteobacteria.

lodopropane targets methyl corrinoid, the central molecule for both anabolic and catabolic pathways in methanogens. In the presence of iodopropane, methyl corrinoid binds to a propyl group instead of a methyl group, inhibiting the pathways requiring the methyl groups, thus inhibiting growth. ${ }^{67}$ Vamshi Krishna and Venkata Mohan ${ }^{65}$ describe pre-treating anaerobic sludge prior to use a SCMFC, with $50 \mathrm{mM}$ 2-iodopropane in anaerobic conditions for 24 hours. Compared

This article is protected by copyright. All rights reserved. 
to control mixed culture sludge, power density increased from $92.08 \mathrm{~mW} \mathrm{~m}^{-2}$ to $180.55 \mathrm{~mW} \mathrm{~m}^{-2}$, whilst CE increased from $2.89 \%$ to $6.188 \%$. A clear shift in microbial community make-up on the bioanode was also observed. In the treated MFCs compared to controls, a huge proportional decrease in Firmicutes species and Caldiserica species was observed, along with a huge proportional increase in proteobacteria.

\section{Quorum sensing}

Quorum sensing is defined as the regulation of gene expression in response to fluctuations in cellpopulation density. ${ }^{68}$ Quorum sensing bacteria produce and release chemical signal molecules referred to as quorum sensing molecules (QSMs), which increase in concentration as a function of cell density. ${ }^{69}$ The detection of a minimal threshold stimulatory concentration of a QSM leads to an alteration in gene expression. ${ }^{70}$ Certain QSMs transcribe genes for biofilm formation, ${ }^{71}$ making this an area of research that has potential for anodic improvements.

In Gram-negative bacteria, N-Acyl homoserine lactones (AHLs) are the most common class of QSM. ${ }^{72}$ Chen, et al. found a concentration of $10 \mu \mathrm{M}$ of the AHL, 3OC12-HSL, in a mixed-culture DCMFC, led to a reduction in 'start-up' time from 10 days to 4 days compared to control, in addition to an increase in CE from $28.3 \% \pm 4.1 \%$ to $36.2 \% \pm 5.1 \%{ }^{73}$ In addition confocal laser scanning microscopy (CLSM) analysis showed that all AHLs tested (C4-HSL, C6-HSL and 30C12-HSL) improved biofilm formation.

Monzon, et al. described a SCMFC system with a pure culture of the extremophile $H$. praevalens. ${ }^{74}$ Whilst precise figures were not given, a $95 \%$ increase in biofilm mass, along with a sustained $30 \%$

This article is protected by copyright. All rights reserved. 
increase in power density were reported with the addition of $100 \mathrm{nM}$ 4-hydroxy-1-methyl-2quinolone (a QSM), compared to control.

\section{BIOCATHODE CONSIDERATIONS}

A much greater emphasis in MFC research has been placed on the anode compared to the cathode. However, research interest in the cathode is increasing. The most important attribute of a cathode is its ability to facilitate the oxygen reduction reaction (ORR). The speed at which the ORR takes place is a limiting factor in MFC electricity production. Cathodes are commonly made out of stainless steel or carbon. In order to improve the rate of the ORR, catalysts are coupled with the cathodes. Platinum is widely reported as an ORR catalyst and can be considered the 'Gold Standard' catalyst. In addition to platinum, different abiotic catalysts have been reported. However abiotic catalysts remain expensive and are susceptible to poisoning, thus requiring frequent replacement. An emerging method of cathodic improvement is the use of biological ORR catalysts such as microorganisms and enzymes. The use of such biological elements at the cathode, has given rise to the term 'biocathode'.

\section{Advantages of biocatalysts over abiotic catalysts}

After the 'Gold Standard' platinum catalyst, transition metal compounds and activated carbon are the most widely utilised abiotic ORR catalysts used in MFC cathodes. ${ }^{75-77}$ Compounds such as cobalt tetramethoxyphenylporphyrin (CoTMPP) have been shown to perform similarly to platinum cathodes at reduced cost and increased sustainability. ${ }^{78,79}$ However these catalysts remain expensive and are susceptible to poisoning, thus requiring frequent replacement. Wastewater constituents such as amino acids, sulphates and some organic dyes contribute to abiotic catalyst poisoning. ${ }^{77,80}$ Poisoned cathodes show a small reduction peak in cyclic voltammetry analysis, demonstrating their

This article is protected by copyright. All rights reserved. 
diminished ORR catalytic potential. ${ }^{81,82}$ An energy intensive, unsustainable process is used in platinum production, conflicting with the desire for MFCs to represent an environmentally friendly alternative energy source. ${ }^{83}$ Biocathodes can be much less cost prohibitive compared to abiotic cathodes, especially after initial investment. ${ }^{84}$ Due to a greater resistance to poisoning compared to platinum catalysed cathodes, cathode servicing intervals may be improved ${ }^{85}$ In addition to catalysing the ORR, some catalysts can further assist in the bioremediation of wastewater that may not be fully addressed in the anode chamber, such as the reduction of nitrates, sulphates and dyes. $^{86-89}$

\section{Bacterial biocathodes}

The growth of a bacterial biofilm on the cathode is rarely avoided and often reported. ${ }^{82}$ Whilst in most cases this biofilm is regarded to be detrimental or uninfluential, it may in fact suggest that there is some biological niche to be exploited by suitably equipped bacteria. ${ }^{90}$ Similar to bacteria that can donate electrons (ie. exoelectrogens), bacteria have been isolated that can accept electrons as part of their normal metabolism. ${ }^{91}$ The ability to utilise free electrons in the absence of a conventional, carbon based electron source enables these electrophillic bacteria to thrive on the electrically rich cathode surface. Hybrid systems have been developed that utilise both abiotic transition metal compounds and bacterial biofilms as ORR catalysts on the cathode..$^{92}$ In such hybrid systems, oxygen can be produced by microorganisms enhancing transition metal oxidation, increasing the rate of electron acceptation by oxygen and thus increasing MFC power output. ${ }^{93}$

Stability and efficacy are major issues requiring improvement in biocathodes. Maintaining bacterial cultures in an industrial wastewater treatment setting can be challenging. Different microorganisms have different nutrient requirements and have differing levels of sensitivity to changes in the

This article is protected by copyright. All rights reserved. 
environment. In a manner similar to methanogen contamination at the anode (see section entitled "Methanogenic inhibition"), the cathode can also become contaminated by opportunistic microorganisms, which reduce the cathodic ORR efficiency. Their development is more prevalent in rich catholytes with high COD values. Methods to combat the development of ORR reducing bacteria at the cathode should be developed, in addition to methods with favour the growth of ORR increasing bacteria. One such method for promoting ORR increasing bacteria is potentiostatic enrichment, wherein a poised electrode encourages the growth of ORR catalysing microorganisms. ${ }^{91,94}$ In the absence of a carbon source, electrophilic bacterial cells are positively selected for. It has been reported that potentiostatically enriched aerobic bacterial biocathodes can have a similar performance to platinum catalysed cathodes. ${ }^{91}$

Potentiostatic enrichment can also enable the discovery and isolation of effective ORR rate increasing microorganisms. Such microorganisms can be cultured and inoculated into the cathode as a method of increasing their cathodic prevalence..$^{95}$ In studies assessing bacterial biocathodic makeup, proteobacterial phyla have been found to dominate cathodic biofilms, with alphaproteobacteria and gammaproteobacteria reported as the most abundant classes. ${ }^{96,97}$

Unlike DCMFCs, in SCMFCs, bacterial biocathodic cultures must grow in an anaerobic environment, as the interior of the air-breathing cathode is in contact with the anaerobic anolyte. Consequently the advantageous groups of microorganisms are expected to differ between DCMFCs and SCMFCs. Some investigations into immobilising microorganisms onto the cathode has been conducted, triggering an area for future research. ${ }^{98}$

\section{Enzymatic biocathodes}

This article is protected by copyright. All rights reserved. 
ORR catalysing enzymes, including bilirubin oxidase, laccase and other peroxidases have been reported as affective in MFC cathodes (Table 3). ${ }^{53,88,99}$ Bilirubin oxidase, for example has been successfully utilised in SCMFCs as an ORR catalyst, performing better than platinum. ${ }^{53}$ There are two main types of ORR catalysing enzymatic biocathodes; biocathodes with enzymes immobilized onto their surface, and microorganisms harbouring enzymes in-situ. A major advantage of immobilized enzymatic biocathodes over bacterial biocathodes is that they do not need to be provided with nutrients. However, this key advantage is often diminished by limitations of the immobilisation and additional costs. In terms of industrial application, wastewaters with a circumneutral $\mathrm{pH}$ are generally the most conducive to optimal enzyme activity. ${ }^{100}$ For wastewater with more extreme $\mathrm{pH}$ values and higher level salinity, researchers should look to enzymes produced by extremophiles naturally adapted to those conditions. ${ }^{24,101}$

Various methods of enzyme immobilization have been reported, including enzyme encapsulation in silica and the immobilisation of single enzyme nanoparticles on nanostructured matrices. ${ }^{88,102}$ Immobilizing enzymes at a close proximity to the cathode surface, enhances systemic efficiency. ${ }^{102}$ ORR rate improving enzymes have been shown to require an active site - electrode distance of no more than 20 Ångströms (Å) for direct electron transfer to occur. ${ }^{103}$

Using a host microorganism to produce, and extracellularly secrete the desired enzyme in-situ during MFC operation is potentially a more cost-effective alternative. Examples include the use of white rot fungi for the in-situ production of laccases in the cathodic chamber. ${ }^{104,105}$ However, contamination with proteolytic bacteria and enzyme inhibitors may prove problematic with this technique. Contamination often arises from the aeration of the cathodic chamber and potentially from bacterial infiltration across a damaged PEM. In addition to the method of extracellularly secreting enzymes, methods which involve cell membrane-bound enzymes have been investigated. One example is 
surface display of $\mathrm{O}_{2}$ reducing enzymes in yeast, which enables the regeneration and immobilisation of the enzyme. ${ }^{106} \mathrm{~A}$ drawback, however, is that the native metabolism of the yeast host is in competition with the cathodic ORR's demand for oxygen, ${ }^{107}$ reducing systemic performance. A method of addressing this drawback is the addition of electron transport chain inhibitors such as antimycin $A .{ }^{108}$ The enzyme delivery methods mentioned should be the focus future research, with synthetic biology investigated as a potential solution.

\section{EXTERNAL RESISTANCE}

An important consideration in MFC systems is the effect of external resistance. External resistance is of importance as it can affect the nature of the microbes selected at both the anode and the cathode. The ohmic (or internal) resistance $\left(R_{\text {int }}\right)$ refers to the resistance of the electrodes, electrolytes and interconnections to electron and proton transport processes in the MFC. It is estimated by conducting polarisation tests and calculating the slope of the polarization curve at the linear (ohmic) region. ${ }^{109}$ The external resistance $\left(R_{\text {ext }}\right)$ controls the flow of electrons from the anode to the cathode, affecting potential (V) and current (I) outputs of MFCs according to Ohm's Law (V = I

$R_{\text {ext }}$ ). The power output (W) is consequently affected by the external resistance, $W=I^{2} R_{\text {ext. }}{ }^{110}$ Theoretically, MFC power output is maximised when the external resistor connected to the cell is equal to the total internal resistance. ${ }^{111}$ The external resistance has been investigated as an optimisation parameter in many studies. There are two general branches of these studies: The first is to compare the performance of different external loads on a given MFC system. The second is to vary the external load during MFC operation and compare to a control. In laboratory tests, MFCs are often operated with a constant external resistance. Meanwhile variations in operating conditions and the processes of biofilm growth and decay lead to significant changes of the internal resistance over time. This inevitably results in a mismatch between the internal and the external resistances, therefore decreasing MFC power output. ${ }^{112}$

This article is protected by copyright. All rights reserved. 
Fernando, et al. examined external resistance as a potential tool for influencing azo dye reductive decolourisation kinetics in MFCs. ${ }^{113}$ In the study, the internal resistance of the MFC systems varied between $655 \pm 2.2 \Omega-1020 \pm 3.7 \Omega$ at all tested external resistances. Different fixed external resistances in the range of $10 \Omega$ to $46 \mathrm{k} \Omega$ were applied to otherwise identical MFCs. The maximum power densities obtained at $2.2 \mathrm{k} \Omega$ external resistance were significantly higher than those obtained at external resistances $50 \Omega$ and $46 \mathrm{k} \Omega$. Rismani-Yazdi, et al. conducted a study in which four fixed external resistances $(20,249,480$ and $1000 \Omega)$ were tested by operating parallel MFCs independently at constant circuit loads for 10 weeks. ${ }^{110}$ Interestingly, in this study, where the ohmic resistance values were calculated to be between $301-382 \Omega$, the maximum power density was observed in the MFC with $20 \Omega$ external resistance, followed by $249 \Omega, 1000 \Omega$ and finally $480 \Omega$. These results did not conform to the theoretical expectation that power density should increase the closer the external load is in value to the ohmic resistance. Many studies have shown bioanodic microbial community differences due to different external loads by DGGE analysis. ${ }^{110,42}$ Changes in MFC design and operational conditions affect the bacterial dynamics and metabolism, which in turn influence the current generation. ${ }^{110}$ Whilst acknowledging differences in external resistance leads to differences in anodic microbial community structure, Lyon, et al. questions the significance of this finding, as in their study, different communities were capable of producing the similar levels of power production, highlighting how dynamic MFC systems are. ${ }^{114}$ Buitrón, et al. showed that MFCs seem to 'adapt' to the external resistance to which they are subjected to. ${ }^{115}$ For example, an MFC 'adapted' to an external resistance of $1000 \Omega$, generated current and power densities of $292.8 \mathrm{~mA} \mathrm{~m}$ ' ${ }^{2}$ and $49.8 \mathrm{~mW} \mathrm{~m}^{-2}$ respectively. However, when an identical MFC 'adapted' to an external resistance of $220 \Omega$, was suddenly applied to a $1000 \Omega$ resistor, a reduction in current and power densities of $40.1 \%$ and $35.7 \%$ respectively was observed. The electricity production was strongly influenced by the external resistance at which the cell was 'adapted'. According to Buitrón, et al., ${ }^{116}$ electroactive 
bacteria acclimate properly to each change of external resistance (a selective pressure), promoting higher current density in time.

The second branch of external resistance studies has been to vary the external resistance during operation. Grondin, et al. designed a system which intermittently connected the resistor in a connected/disconnected (on/off) manner. ${ }^{112}$ A $10 \Omega$ external load was connected for a period of 5 seconds, followed by disconnection for a period of 2 seconds, with the on/off process repeated throughout operation. Results were compared to a control MFC with a constantly connected $20 \Omega$ external load. The internal resistance of the MFC in this study was estimated to be $19-24 \Omega$. Although the variable external resistance MFC had an 'average power output per cycle' value of 1.73 $\pm 0.03 \mathrm{~mW}$, lower than the constant external resistance MFC, with $2.1 \mathrm{~mW}$, the findings are significant, as they show that an MFC could be operated without significant losses in power output, even when the external resistance values are below the internal resistance. Buitrón, et al. compared a control to an MFC which was connected to a digital potentiometer with an array of fixed resistance values to vary the external load from 0 to $50 \mathrm{k} \Omega .{ }^{116}$ The external resistance was varied $\pm 20 \%$ according to system-calculated internal resistance. The external resistance which the system selected was that which theoretically provided the highest maximum output power, through estimation of the MFC's internal resistance. This MFC was compared to an otherwise identical MFC with a constant resistance of $1500 \Omega$. It was found that the MFC with the varied external resistance, which took into account the systems present internal resistance had its 'start-up' time halved from 8 to 4 days.

\section{CONCLUSIONS}

This review identifies major development areas in wastewater treating MFCs with emphasis on bioelectrodes. More research has been conducted into anodic development than into cathodic

This article is protected by copyright. All rights reserved. 
development. However, research interest in biologically catalysed cathodes has increased in recent years. Although this review is not exhaustive, we have presented some of the major developments and challenges in the field and suggested areas for future research.

For industrial application, the goal of bioanodic development is a highly efficient $E A B$, with a strong resilience to variation in wastewater composition, which requires infrequent servicing. Pure cultures are particularly useful for laboratory testing of the impact of specific factors, in order to reduce variables. Extremophile, pure or mixed, cultures are of particular interest for more specialised industrial applications and present an area worthy of greater interest. In the case of undefined mixed cultures, the choice of inoculum is of utmost importance, as it is from this source that all anodic microbial diversity is derived. Soil has been reported as the best inoculum source for achieving high exoelectrogenic diversity, whilst wastewater itself has been reported as a poor source. Mixed cultures consisting of a fungal component are an emerging direction for future research. MFCs have been shown to be robust systems, capable of treating a variety of different types of wastewater. The strategy could be explored of first exposing the anode to an enrichment medium, which selects for the growth of the most advantageous exoelectrogenic species, followed by exposure to the wastewater being treated. In many industrial scale-up models, an undefined anodic mixed culture is used. The growth of non-exoelectrogens, in particular methanogens is a recurring challenge when using such cultures. In this review a variety of methods to reduce the presence of methanogens were discussed. Exploitation of external resistance for MFC performance requires further improvement; however a study presented in this review questions its importance as a factor for improvement. Both perspectives should be considered before embarking on further research in this line. Methods to achieve enhanced anodic EABs, in particular the exploitation of bacterial quorum sensing were reported. Little research has been conducted in this area to date, and

This article is protected by copyright. All rights reserved. 
along with quorum quenching, it represents a developing niche in the field. In addition to anodic development, quorum sensing and quorum quenching should be examined in biocathodic research.

The main goal of biocathodic development for industrial application is the maximisation of the ORR rate using elements which are robust, cost-affective, and do not require frequent servicing. The aim to produce biocathodes which attain a superior performance to the 'gold standard' catalyst, platinum, will be a great advance in the field. In the case of immobilized enzymatic biocathodes, research should focus on improving enzymatic activity, stability, and lifespan. For bacterial biocathodes, various ORR rate improving species should be investigated, with the downstream goal of developing standard procedures for their use. The hybrid technique of utilising bacteria to maintain ORR rate improving enzymes in-situ may present the most effective solution.

Throughout the literature, the main performance metrics are power density, current density, COD reduction and CE. These performance metrics are explained in detail in Logan et al. ${ }^{117}$ and do not form a comprehensive list of all possible MFC performance metrics. For instance, He suggested that energy as opposed to power may be a more useful measure. ${ }^{118}$ There are inconsistencies in reporting, with some studies reporting power density in $\mathrm{W} \mathrm{m}^{-2}$ and others in $\mathrm{W} \mathrm{m}^{-3}$. Such inconsistencies, in addition to variation in reactor size and design make meaningful comparisons between different studies difficult. Additionally, whilst the use of the 'gold standard' cathodic catalyst, platinum, produces superior results than other methods, it is expensive and its use can lead to microbial poisoning, making its use in industrial settings impractical.

Finally it is important to look at microbial fuel cells in their broader context - beyond wastewater treatment and electricity production - as systems capable of producing useful products such as 
drugs or biopolymers from waste. These developing applications in addition to the promise of environmentally friendly wastewater treatment, present potentially lucrative opportunities as well as contribution in the circular economy.

\section{ACKNOWLEDGEMENTS}

This work is part of a Newton-Mosharafa Institutional Links project funded by the UK-based British Council (ID 261690585) and the Egypt-based Science and Technology Development Fund (ID 27662).

\section{REFERENCES}

1. Jiang $C$, Yang $Q$, Wang D, Zhong $Y$, Chen F, Li X, Zeng G, Li X and Shang, M, Simultaneous perchlorate and nitrate removal coupled with electricity generation in autotrophic denitrifying biocathode microbial fuel cell. Chem Eng J 308:783-790 (2017).

2. Rabaey K and Verstraete W, Microbial fuel cells: novel biotechnology for energy generation. Trends Biotechnol 23:291-298 (2005).

3. Chaudhuri SK and Lovely DR, Electricity generation by direct oxidation of glucose in mediatorless microbial fuel cells. Nat Biotechnol 21:1229-1232 (2003).

4. Hartshorne RS, Reardon CL, Ross D, Nuester J, Clarke TA, Gates AJ, Mills PC, Fredrickson JK, Zachara JM, Shi L, Beliaev AS, Marshall MJ, Tien M, Brantley S, Butt JN and Richardson DJ, Characterization of an electron conduit between bacteria and the extracellular environment. Proc Natl Acad Sci USA 106:22169-22174 (2009).

5. Marsili E, Baron DB, Shikhare ID, Coursolle D, Gralnick JA and Bond DR, Shewanella secretes flavins that mediate extracellular electron transfer. Proc Natl Acad Sci USA 105:3968-3973 (2008).

6. Reguera G, Mccarthy KD, Mehta T, Nicoll JS, Tuominen MT and Lovley DR, Extracellular electron transfer via microbial nanowires. J Nat Prod 435:1098-1101 (2005).

This article is protected by copyright. All rights reserved. 
7. Logan B, Exoelectrogenic bacteria that power microbial fuel cells, Nat Rev Microbiol 7:375381 (2009).

8. Schröder U, Anodic electron transfer mechanisms in microbial fuel cells and their energy efficiency. Phys Chem Chem Phys 9:2619-2629 (2007).

9. Ledezma P, Donose B, Freguia S and Keller J, Oxidised stainless steel: a very effective electrode material for microbial fuel cell bioanodes but at high risk of corrosion. Electrochim Acta 158:356-360 (2015).

10. Huang L, Li X, Ren $Y$ and Wang $X$, In-situ modified carbon cloth with polyaniline/graphene as anode to enhance performance of microbial fuel cell. Int J Hydrogen Energy 41:11369-11379 (2016).

11. Jia X, He Z, Zhang X and Tian X, Carbon paper electrode modified with $\mathrm{TiO}_{2}$ nanowires enhancement bioelectricity generation in microbial fuel cell. Synth Met 215:170-175 (2016).

12. Liao Q, Zhang J, Li J, Ye D, Zhu X and Zhang B, Increased performance of a tubular microbial fuel cell with a rotating carbon-brush anode. Biosens Bioelectron 63:558-561 (2015).

13. Pramanik S and Rana M, Bioelectricity Generation using Carbon Felt Electrode in Microbial Fuel Cell (MFC) Inoculated with Mixed Cultures. Tr Ren Energy 3:129-140 (2017).

14. Jiang D, Curtis M, Troop E, Scheible K, McGrath J, Hu B, Suib S, Raymond D and Li B, A pilotscale study on utilizing multi-anode/cathode microbial fuel cells (MAC MFCs) to enhance the power production in wastewater treatment. Int J Hydrogen Energy 36:876-884 (2011).

15. Taskan E and Hasar H, Comprehensive Comparison of a New Tin-Coated Copper Mesh and a Graphite Plate Electrode as an Anode Material in Microbial Fuel Cell. Appl Biochem Biotechnol 175:2300-2308 (2014).

16. Wu S, He W, Yang W, Ye Y, Huang $X$ and Logan B, Combined carbon mesh and small graphite fiber brush anodes to enhance and stabilize power generation in microbial fuel cells treating domestic wastewater. J Power Sources 356:348-355 (2017).

This article is protected by copyright. All rights reserved. 
17. Lanas V, Ahn Y and Logan B, Effects of carbon brush anode size and loading on microbial fuel cell performance in batch and continuous mode. J Power Sources 247:228-234 (2014).

18. Moon J, Kondaveeti S, Lee T, Song Y and Min B, Minimum interspatial electrode spacing to optimize air-cathode microbial fuel cell operation with a membrane electrode assembly. Bioelectrochem 106:263-267 (2015).

19. Zhang, $P$, Liu, J, Qu, $Y$, Zhang, J, Zhong, $Y$ and Feng, $Y$, Enhanced performance of microbial fuel cell with a bacteria/multi-walled carbon nanotube hybrid biofilm. J Power Sources 361:318325 (2017).

20. Biffinger J, Byrd J, Dudley B and Ringeisen B, Oxygen exposure promotes fuel diversity for Shewanella oneidensis microbial fuel cells. Biosens Bioelectron 23:820-826 (2008).

21. Kim B, Chang I and Gadd G, Challenges in microbial fuel cell development and operation. App/ Microbiol Biotechnol 76:485-494 (2007).

22. Ringeisen B, Henderson E, Wu P, Pietron J, Ray R, Little B, Biffinger J and Jones-Meehan J, High Power Density from a Miniature Microbial Fuel Cell Using Shewanella oneidensis DSP10. Environ Sci Technol 40:2629-2634 (2006).

23. Grattieri M, Suvira M, Hasan $\mathrm{K}$ and Minteer S, Halotolerant extremophile bacteria from the Great Salt Lake for recycling pollutants in microbial fuel cells. J Power Sources 356:310-318 (2017).

24. Dopson M, Ni G and Sleutels T, Possibilities for extremophilic microorganisms in microbial electrochemical systems. FEMS Microbiol Rev 40:164-181 (2015).

25. Monzon O, Yang Y, Li Q and Alvarez P, Quorum sensing autoinducers enhance biofilm formation and power production in a hypersaline microbial fuel cell. Biochem Eng J 109:222227 (2016).

26. Abrevaya X, Sacco N, Mauas P and Cortón E, Archaea-based microbial fuel cell operating at high ionic strength conditions. Extremophiles 15:633-642 (2011).

This article is protected by copyright. All rights reserved. 
27. Qu Y, Feng Y, Wang X and Logan B, Use of a Coculture To Enable Current Production by Geobacter sulfurreducens. Appl Environ Microbiol 78:3484-3487 (2012).

28. Hassan S, Kim Y and Oh S, Power generation from cellulose using mixed and pure cultures of cellulose-degrading bacteria in a microbial fuel cell. Enzyme Microb Technol. 51:269-273 (2012).

29. Ren Z, Ward T and Regan J, Electricity Production from Cellulose in a Microbial Fuel Cell Using a Defined Binary Culture. Environ Sci Technol 41:4781-4786 (2007).

30. Fernández de Dios M, del Campo A, Fernández F, Rodrigo M, Pazos M and Sanromán $M$, Bacterial-fungal interactions enhance power generation in microbial fuel cells and drive dye decolourisation by an ex situ and in situ electro-Fenton process. Bioresour Technol 148:39-46 (2013).

31. Agler M, Wrenn B, Zinder S and Angenent L, Waste to bioproduct conversion with undefined mixed cultures: the carboxylate platform. Trends Biotechnol 29:70-78 (2011).

32. Doyle L and Marsili E, Methods for enrichment of novel electrochemically-active microorganisms. Bioresour Technol 195:273-282 (2015).

33. Gude, VG, Wastewater treatment in microbial fuel cells - an overview. J Clean Prod 122:287307 (2016).

34. Li W, Yu H and He Z, Towards sustainable wastewater treatment by using microbial fuel cellscentered technologies. Energy Environ Sci 7:911-924 (2013).

35. Cheng K, Hu J, Hou H, Liu B, Chen Q, Pan K, Pu W, Yang J, Wu X and Yang C, Aerobic granular sludge inoculated microbial fuel cells for enhanced epoxy reactive diluent wastewater treatment. Bioresour Technol 229:126-133 (2017).

36. Dong, Y, Qu, Y, He, W, Du, Y, Liu, J, Han, X and Feng, Y, A 90-liter stackable baffled microbial fuel cell for brewery wastewater treatment based on energy self-sufficient mode. Bioresour Technol 195:66-72 (2015).

This article is protected by copyright. All rights reserved. 
37. Feng $\mathrm{Y}$, Wang $\mathrm{X}$, Logan $\mathrm{B}$ and Lee $\mathrm{H}$, Brewery wastewater treatment using air-cathode microbial fuel cells. Appl Microbiol Biotechnol 78:873-880 (2008).

38. Kleerebezem R and van Loosdrecht M, Mixed culture biotechnology for bioenergy production. Curr Opin Biotechnol 18:207-212 (2007).

39. Rismani-Yazdi H, Carver S, Christy A, Yu Z, Bibby K, Peccia J and Tuovinen O, Suppression of methanogenesis in cellulose-fed microbial fuel cells in relation to performance, metabolite formation, and microbial population. Bioresour Technol 129:281-288 (2013).

40. Zhang B, Zhang J, Liu Y, Hao C, Tian C, Feng C, Lei Z, Huang W and Zhang Z, Identification of removal principles and involved bacteria in microbial fuel cells for sulfide removal and electricity generation. Int J Hydrogen Energy. 38: 14348-14355 (2013).

41. Kiely P, Rader G, Regan J and Logan B, Long-term cathode performance and the microbial communities that develop in microbial fuel cells fed different fermentation endproducts. Bioresour Technol 102:361-366 (2011).

42. Zhang L, Li C, Ding L, Xu K and Ren H, Influences of initial pH on performance and anodic microbes of fed-batch microbial fuel cells. J Chem Technol Biotechnol 86:1226-1232 (2011).

43. Pant $D$, Van Bogaert $G$, Diels $L$ and Vanbroekhoven $K, A$ review of the substrates used in microbial fuel cells (MFCs) for sustainable energy production. Bioresour Technol 101:15331543 (2010).

44. Roustazadeh Sheikhyousefi, P, Nasr Esfahany, M, Colombo, A, Franzetti, A, Trasatti, S and Cristiani, $\mathrm{P}$, Investigation of different configurations of microbial fuel cells for the treatment of oilfield produced water. Appl Energy 192:457-465 (2017).

45. Sevda S, Dominguez-Benetton X, Vanbroekhoven K, Sreekrishnan T and Pant D, Characterization and comparison of the performance of two different separator types in aircathode microbial fuel cell treating synthetic wastewater. Chem Eng J 228:1-11 (2013).

This article is protected by copyright. All rights reserved. 
46. Wang, Y, Liu, X, Li, W, Li, F, Wang, Y, Sheng, G, Zeng, R and Yu, H, A microbial fuel cellmembrane bioreactor integrated system for cost-effective wastewater treatment. Appl Energy 98:230-235 (2012).

47. Xie, X, Ye, M, Hu, L, Liu, N, Mcdonough, JR, Chen, W, Alshareef, HN, Criddle, CS and Cui, Y, Carbon nanotube-coated macroporous sponge for microbial fuel cell electrodes. Energy Enviorn Sci 5:5265-5270 (2012).

48. Pandey P, Shinde V, Deopurkar R, Kale S, Patil S and Pant D, Recent advances in the use of different substrates in microbial fuel cells toward wastewater treatment and simultaneous energy recovery. Appl Energy 168:706-723 (2016).

49. Mansoorian, H, Mahvi, A, Jafari, A, Amin, M, Rajabizadeh, A and Khanjani, N, Bioelectricity generation using two chamber microbial fuel cell treating wastewater from food processing. Enzyme Microb Technol 52:352-357 (2013).

50. Martin E, Savadogo O, Guiot S and Tartakovsky B, The influence of operational conditions on the performance of a microbial fuel cell seeded with mesophilic anaerobic sludge. Biochem Eng J 51:132-139 (2010).

51. Margaria V, Tommasi T, Pentassuglia S, Agostino V, Sacco A, Armato C, Chiodoni A, Schilirò T and Quaglio $\mathrm{M}$, Effects of $\mathrm{pH}$ variations on anodic marine consortia in a dual chamber microbial fuel cell. Int J Hydrogen Energy 42:1820-1829 (2017).

52. Behera $\mathrm{M}$ and Ghangrekar $\mathrm{M}$, Performance of microbial fuel cell in response to change in sludge loading rate at different anodic feed pH. Bioresour Technol 100:5114-5121 (2009).

53. Santoro C, Babanova S, Atanassov P, Li B, leropoulos I, Cristiani P, High Power Generation by a Membraneless Single Chamber Microbial Fuel Cell (SCMFC) Using Enzymatic Bilirubin Oxidase (BOx) Air-Breathing Cathode. J Electrochem Soc 160:720-726 (2013).

54. He Z, Huang $\mathrm{Y}$, Manohar $\mathrm{A}$ and Mansfeld F, Effect of electrolyte $\mathrm{pH}$ on the rate of the anodic and cathodic reactions in an air-cathode microbial fuel cell. Bioelectrochem 74:78-82 (2008).

This article is protected by copyright. All rights reserved. 
55. Cheng K, Ho G and Cord-Ruwisch R, Anodophilic Biofilm Catalyzes Cathodic Oxygen Reduction. Environ Sci Technol 44:518-525 (2010).

56. Jadhav $\mathrm{G}$ and Ghangrekar $\mathrm{M}$, Performance of microbial fuel cell subjected to variation in $\mathrm{pH}$, temperature, external load and substrate concentration. Bioresour Technol 100:717-723 (2009).

57. Rozendal R, Hamelers $\mathrm{H}$ and Buisman C, Effects of Membrane Cation Transport on pH and Microbial Fuel Cell Performance. Environ Sci Technol 40:5206-5211 (2006).

58. Oliveira V, Simões M, Melo L and Pinto A, Overview on the developments of microbial fuel cells. Biochem Eng J 73:53-64 (2013).

59. Luo H, Xu P, Roane T, Jenkins P and Ren Z, Microbial desalination cells for improved performance in wastewater treatment, electricity production, and desalination. Bioresour Technol 105:60-66 (2012).

60. Borole A, Hamilton C, Vishnivetskaya T, Leak D, Andras C, Morrell-Falvey J, Keller M and Davison B, Integrating engineering design improvements with exoelectrogen enrichment process to increase power output from microbial fuel cells. J Power Sources 191(2):520-527 (2009).

61. Kadier A, Kalil M, Chandrasekhar K, Mohanakrishna G, Saratale G, Saratale R, Kumar G, Pugazhendhi A and Sivagurunathan P, Surpassing the current limitations of high purity $\mathrm{H}_{2}$ production in microbial electrolysis cell (MECs): Strategies for inhibiting growth of methanogens. Bioelectrochem 119:211-219 (2018).

62. Sakdaronnarong, C, Thanosawan, S, Chaithong, S, Sinbuathong, N and Jeraputra, C, Electricity production from ethanol stillage in two-compartment MFC. Fuel 107:382-386 (2013).

63. Karthikeyan, R, Cheng, K, Selvam, A, Bose, A and Wong, J, Bioelectrohydrogenesis and inhibition of methanogenic activity in microbial electrolysis cells - A review. Biotechnol Adv 35(6):758-771 (2017).

64. Franks, A and Nevin, K, Microbial Fuel Cells, A Current Review. Energies 3(5):899-919 (2010).

This article is protected by copyright. All rights reserved. 
65. Vamshi Krishna, K and Venkata Mohan, S. Selective enrichment of electrogenic bacteria for fuel cell application: Enumerating microbial dynamics using MiSeq platform. Bioresour Technol 213146-154 (2016).

66. Tartakovsky, B, Manuel, M, Neburchilov, V, Wang, H and Guiot, S, Biocatalyzed hydrogen production in a continuous flow microbial fuel cell with a gas phase cathode. J Power Sources 182(1):291-297 (2008).

67. Simpson, P and Whitman, W, Methanogenesis: Ecology, Physiology, Biochemistry \& Genetics, ed by Ferry, J.G. Springer, Boston, MA, pp 445-472 (1993).

68. Põllumaa, L, Alamäe, T and Mäe, A, Quorum Sensing and Expression of Virulence in Pectobacteria. Sensors 12:3327-3349 (2012).

69. Li, Y and Tian, $\mathrm{X}$, Quorum Sensing and Bacterial Social Interactions in Biofilms. Sensors 12:2519-2538 (2012).

70. Miller, M and Bassler, B, Quorum Sensing in Bacteria. Annu Rev Microbiol 55:165-199 (2001).

71. Solano, C, Echeverz, M and Lasa, I, Biofilm dispersion and quorum sensing. Curr Opin Microbiol 18:96-104 (2014).

72. Papenfort, K and Bassler, B, Quorum sensing signal-response systems in Gram-negative bacteria. Nat Rev Microbiol 14:576-588 (2016).

73. Chen, $S$, Jing, $X$, Tang, J, Fang, $Y$ and Zhou, $S$, Quorum sensing signals enhance the electrochemical activity and energy recovery of mixed-culture electroactive biofilms. Biosens Bioelectron 97:369-376 (2017).

74. Monzon, $\mathrm{O}$, Yang, $\mathrm{Y}, \mathrm{Li}, \mathrm{Q}$ and Alvarez, $\mathrm{P}$, Quorum sensing autoinducers enhance biofilm formation and power production in a hypersaline microbial fuel cell. Biochem Eng J 109:222227 (2016).

75. Kodali, M, Santoro, C, Serov, A, Kabir, S, Artyushkova, K, Matanovic, I and Atanassov, P, Air Breathing Cathodes for Microbial Fuel Cell using Mn-, Fe-, Co- and Ni- containing Platinum Group Metal-free Catalysts. Electrochim Acta 231:115-124 (2017).

This article is protected by copyright. All rights reserved. 
76. Zhang, $\mathrm{Y}$, Sun, J, Hu, Y, Li, S and $\mathrm{Xu}, \mathrm{Q}$, Bio-cathode materials evaluation in microbial fuel cells: A comparison of graphite felt, carbon paper and stainless steel mesh materials. Int J Hydrogen Energy 37:16935-16942 (2012).

77. Köhler, C, Bleck, L, Frei, M, Zengerle, R \& Kerzenmacher, S, Poisoning of Highly Porous Platinum Electrodes by Amino Acids and Tissue Fluid Constituents. ChemElectroChem 2:17851793 (2015).

78. Zhao, F, Harnisch, F, Schröder, U, Scholz, F, Bogdanoff, P and Herrmann, I, Application of pyrolysed iron(II) phthalocyanine and CoTMPP based oxygen reduction catalysts as cathode materials in microbial fuel cells. Electrochem Commun 7:1405-1410 (2005).

79. Chen, G, Choi, S, Lee, T, Lee, G, Cha, J and Kim, C, Application of biocathode in microbial fuel cells: cell performance and microbial community. Appl Microbiol Biotechnol 79:379-388 (2008).

80. Santoro, C, Serov, A, Villarrubia, CWN, Stariha, S, Babanova, S, Artyushkova, K, Schuler, AJ and Atanassov, P, High catalytic activity and pollutants resistivity using Fe-AAPyr cathode catalyst for microbial fuel cell application. Nature: Scientific Reports 5:1-10 (2015).

81. Chen, C, Halford, A, Walker, M, Brennan, C, Lai, SC, Fermin, DJ, Unwin, PR and Rodriguez, P, Electrochemical characterization and regeneration of sulfur poisoned Pt catalysts in aqueous media. J Electroanal Chem 816:138-148 (2018).

82. He, Z and Angenent, L, Application of Bacterial Biocathodes in Microbial Fuel Cells. Electroanalysis 18:2009-2015 (2006).

83. Clauwaert, P, Van Der Ha, D, Boon, N, Verbeken, K, Verhaege, M, Rabaey, K and Verstraete, W, Open Air Biocathode Enables Effective Electricity Generation with Microbial Fuel Cells. Enviorn Sci Technol 41:7564-7569 (2007).

84. Rahimnejad, M, Adhami, A, Darvari, S, Zirepour, A and Oh, S, Microbial fuel cell as new technology for bioelectricity generation: A review. Alexandria Eng J 54:745-756 (2015).

This article is protected by copyright. All rights reserved. 
85. Santoro, C, Serov, A, Gokhale, R, Rojas-Carbonell, S, Stariha, L, Gordon, J, Artyushkova, K and Atanassov, P, A family of Fe-N-C oxygen reduction electrocatalysts for microbial fuel cell (MFC) application: Relationships between surface chemistry and performances. Appl Catal B: Environ 205:24-33 (2017).

86. Sotres, A, Cerrillo, M, Viñas, M \& Bonmatí, A, Nitrogen removal in a two-chambered microbial fuel cell: Establishment of a nitrifying-denitrifying microbial community on an intermittent aerated cathode. Chem Eng J 284:905-916 (2016).

87. Jiang, C, Yang, Q, Wang, D, Zhong, Y, Chen, F, Li, X, Zeng, G, Li, X and Shang, M, Simultaneous perchlorate and nitrate removal coupled with electricity generation in autotrophic denitrifying biocathode microbial fuel cell. Chem Eng J 308:783-790 (2017).

88. Mani, P, Keshavarz, T, Chandra, T and Kyazze, G, Decolourisation of Acid orange 7 in a microbial fuel cell with a laccase-based biocathode: Influence of mitigating $\mathrm{pH}$ changes in the cathode chamber. Enzyme Microb Technol 96170-176 (2017).

89. Park, Y, Park, S, Nguyen, V, Yu, J, Torres, C, Rittmann, B and Lee, T, (Complete nitrogen removal by simultaneous nitrification and denitrification in flat-panel air-cathode microbial fuel cells treating domestic wastewater. Chem Eng J 316:673-679 (2017).

90. Li, X, Lu, Y, Luo, H, Liu, G and Zhang, R, Microbial stratification structure within cathodic biofilm of the microbial fuel cell using the freezing microtome method. Bioresour Technol 241:384-390 (2017).

91. Milner, E, Popescu, D, Curtis, T, Head, I, Scott, K and Yu, E, Microbial fuel cells with highly active aerobic biocathodes. J Power Sources. 324:8-16 (2016).

92. Rhoads, A, Beyenal, H and Lewandowski, Z, Microbial Fuel Cell using Anaerobic Respiration as an Anodic Reaction and Biomineralized Manganese as a Cathodic Reactant. Environ Sci Technol 39:4666-4671 (2005).

This article is protected by copyright. All rights reserved. 
93. González del Campo, A, Cañizares, P, Rodrigo, M, Fernández, F \& Lobato, J, Microbial fuel cell with an algae-assisted cathode: A preliminary assessment. J Power Sources. 242:638-645 (2013).

94. Mohamed, A, Zmuda, HM, Coats, ER and Beyenal, H, Field Demonstration of Potentiostatically Enriched Microbial Fuel Cell Wastewater Treatment System. The Electrochemical Society Meeting Abstracts. MA2018-01 2263 (2018).

95. Pisciotta, J, Zaybak, Z, Call, D, Nam, J and Logan, B, Enrichment of Microbial Electrolysis Cell Biocathodes from Sediment Microbial Fuel Cell Bioanodes. Appl Environ Microb 78:5212-5219 (2012).

96. Rothballer, M, Picot, M, Sieper, T, Arends, J, Schmid, M, Hartmann, A, Boon, N, Buisman, C, Barrière, $\mathrm{F}$ and Strik, D, Monophyletic group of unclassified $\mathrm{\gamma}$-Proteobacteria dominates in mixed culture biofilm of high-performing oxygen reducing biocathode. Bioelectrochemistry 106:167-176 (2015).

97. Wang, $Z$, Zheng, $Y, X i a o, Y, W u, S, W u, Y, Y a n g, Z$ and $Z$ hao, $F$, Analysis of oxygen reduction and microbial community of air-diffusion biocathode in microbial fuel cells. Bioresour Technol 144:74-79 (2013).

98. Logroño, W, Pérez, M, Urquizo, G, Kadier, A, Echeverría, M, Recalde, C and Rákhely, G, Single chamber microbial fuel cell (SCMFC) with a cathodic microalgal biofilm: A preliminary assessment of the generation of bioelectricity and biodegradation of real dye textile wastewater. Chemosphere 176:378-388 (2017).

99. Christwardana, M, Kim, K and Kwon, Y, Fabrication of Mediatorless/Membraneless Glucose/Oxygen Based Biofuel Cell using Biocatalysts Including Glucose Oxidase and Laccase Enzymes. Nature: Scientific Reports 6:1-10 (2016).

100. Santoro, C, Babanova, S, Erable, B, Schuler, A and Atanassov, P, Bilirubin oxidase based enzymatic air-breathing cathode: Operation under pristine and contaminated conditions. Bioelectrochemistry 108:1-7 (2016).

This article is protected by copyright. All rights reserved. 
101. DasSarma, S and DasSarma, P, Halophiles and their enzymes: negativity put to good use. Curr Opin Microbiol 25:120-126 (2015).

102. Minteer, S, Atanassov, P, Luckarift, $\mathrm{H}$ and Johnson, $\mathrm{G}$, New materials for biological fuel cells. Materials Today 15:166-173 (2012).

103. Kim, J, Jia, $\mathrm{H}$ and Wang, P, Challenges in biocatalysis for enzyme-based biofuel cells. Biotechnol Adv 24:296-308 (2006).

104. Lai, C, Wu, C, Meng, C and Lin, C, Decolorization of azo dye and generation of electricity by microbial fuel cell with laccase-producing white-rot fungus on cathode. Appl Energy 188 :392398 (2017).

105. Wu, C, Liu, X, Li, W, Sheng, G, Zang, G, Cheng, Y, Shen, N, Yang, Y \& Yu, H, A white-rot fungus is used as a biocathode to improve electricity production of a microbial fuel cell. Appl Energy 98:594-596 (2012).

106. Gal, I, Schlesinger, O, Amir, L and Alfonta, L, Yeast surface display of dehydrogenases in microbial fuel-cells. Bioelectrochemistry 112:53-60 (2016).

107. Fishilevich, S, Amir, L, Fridman, Y, Aharoni, A and Alfonta, L, Surface Display of Redox Enzymes in Microbial Fuel Cells. J Am Chem Soc 131:12052-12053 (2009).

108. Szczupak, A, Kol-Kalman, D and Alfonta, L, A hybrid biocathode: surface display of O2reducing enzymes for microbial fuel cell applications. Chem Commun 48:49-51 (2012).

109. Aelterman, $\mathrm{P}$, Versichele, $\mathrm{M}$, Marzorati, $\mathrm{M}, \mathrm{Boon}, \mathrm{N}$ and Verstraete, $\mathrm{W}$, Loading rate and external resistance control the electricity generation of microbial fuel cells with different three-dimensional anodes. Bioresour Technol 99:8895-8902 (2008).

110. Rismani-Yazdi, H, Christy, A, Carver, S, Yu, Z, Dehority, B and Tuovinen, O, Effect of external resistance on bacterial diversity and metabolism in cellulose-fed microbial fuel cells. Bioresour Technol 102:278-283 (2011).

111. Logan, B, Microbial Fuel Cells, ed by Logan, B. John Wiley \& Sons, Hoboken, NJ (2008).

This article is protected by copyright. All rights reserved. 
112. Grondin, F, Perrier, M and Tartakovsky, B, Microbial fuel cell operation with intermittent connection of the electrical load. J Power Sources 208:18-23 (2012).

113. Fernando, E, Keshavarz, T and Kyazze, G, External resistance as a potential tool for influencing azo dye reductive decolourisation kinetics in microbial fuel cells. Int Biodeterior Biodegrad 89:7-14 (2014).

114. Lyon, D, Buret, F, Vogel, T and Monier, J, Is resistance futile? Changing external resistance does not improve microbial fuel cell performance. Bioelectrochemistry 78:2-7 (2010).

115. Buitrón, G and Moreno-Andrade, I, Performance of a Single-Chamber Microbial Fuel Cell Degrading Phenol: Effect of Phenol Concentration and External Resistance. Appl Biochem Biotechnol 174:2471-2481 (2014).

116. Buitrón, G, López-Prieto, I, Zúñiga, I and Vargas, A, Reduction of start-up time in a microbial fuel cell through the variation of external resistance. Energy Procedia 142:694-699 (2017).

117. Logan BE, Hamelers B, Rozendal R, Schröder U, Keller J, Freguia S, Aelterman P, Verstraete W and Rabaey K, Microbial Fuel Cells: Methodology and Technology. Environ Sci Technol 40:5181-5192 (2006).

118. He, Z, Development of Microbial Fuel Cells Needs To Go beyond "Power Density". ACS Energy Lett 2:700-702 (2017).

119. Rajesh $P$, Jadhav D, Ghangrekar M, Improving performance of microbial fuel cell while controlling methanogenesis by Chaetoceros pretreatment of anodic inoculum. Bioresour Technol 180:66-71 (2015).

120. Božic A, Anderson R, Carstens G, Ricke S, Callaway T, Yokoyama M, Wang J and Nisbet D, Effects of the methane-inhibitors nitrate, nitroethane, lauric acid, Lauricidin ${ }^{\circledR}$ and the Hawaiian marine algae Chaetoceros on ruminal fermentation in vitro. Bioresour Technol 100:4017-4025 (2009).

121. Anderson RC, Carstens GE, Miller RK, Callaway TR, Schultz CL, Edrington TS, Harvey RB and Nisbet DJ, Effect of oral nitroethane and 2-nitropropanol administration on methane-

This article is protected by copyright. All rights reserved. 
producing activity and volatile fatty acid production in the ovine rumen. Bioresour Technol

97:2421-2426 (2006).

Table 1. A brief assessment of current challenges facing MFC research

\begin{tabular}{|l|l|l|}
\hline $\begin{array}{l}\text { Development of a } \\
\text { highly robust culture } \\
\text { for a given MFC } \\
\text { application }\end{array}$ & $\begin{array}{l}\text { Reduced service intervals } \\
\text { Greater resistance to process } \\
\text { disturbances }\end{array}$ & $\begin{array}{l}\text { Dabour intensive } \\
\text { Culture needs to tolerate a degree of } \\
\text { wastewater variability }\end{array}$ \\
\hline $\begin{array}{l}\text { Development of MFC } \\
\text { standard operating } \\
\text { procedures }\end{array}$ & $\begin{array}{l}\text { Necessary for industrial } \\
\text { application }\end{array}$ & $\begin{array}{l}\text { Repeated identical performance is } \\
\text { difficult to attain in MFC systems }\end{array}$ \\
\hline $\begin{array}{l}\text { Development of a } \\
\text { bacterial ORR rate } \\
\text { increasing culture }\end{array}$ & $\begin{array}{l}\text { Enables improved comparison } \\
\text { across studies }\end{array}$ & $\begin{array}{l}\text { Coordination across research groups } \\
\text { is required }\end{array}$ \\
\hline $\begin{array}{l}\text { Development of an } \\
\text { immobilized ORR rate } \\
\text { increasing enzymatic } \\
\text { traditional ORR catalysts }\end{array}$ & $\begin{array}{l}\text { Improved power output } \\
\text { Cost reduction when compared to } \\
\text { traditional ORR catalysts }\end{array}$ & $\begin{array}{l}\text { Contamination risks } \\
\text { potentially dangerous }\end{array}$ \\
\hline
\end{tabular}

This article is protected by copyright. All rights reserved. 
Table 2. Comparison of recently reported methanogenic inhibition methods

\begin{tabular}{|l|l|l|}
\hline \multicolumn{1}{|c|}{ Inhibition tool } & \multicolumn{1}{|c|}{ Method of action } & References \\
\hline $\begin{array}{l}\text { Heat shock pre- } \\
\text { treatment }\end{array}$ & $\begin{array}{l}\text { Methanogens are more sensitive to high } \\
\text { temperatures than many exoelectrogens }\end{array}$ & {$[65]$} \\
\hline $\begin{array}{l}\text { lodopropane pre- } \\
\text { treatment }\end{array}$ & $\begin{array}{l}\text { 2-lodopropane inhibits a critical step in } \\
\text { methanogenesis }\end{array}$ & {$[65]$} \\
\hline $\begin{array}{l}\text { Marine algae } \\
\text { Chaetoceros pre- } \\
\text { treatment }\end{array}$ & $\begin{array}{l}\text { Chaetoceros produces hexadecatrienoic acid which } \\
\text { has been found to have methanogen inhibition } \\
\text { properties }\end{array}$ & {$[119][120]$} \\
\hline $\begin{array}{l}\text { Nitroethane } \\
\text { treatment }\end{array}$ & $\begin{array}{l}\text { Nitroethane has been shown to inhibit substrates } \\
\text { used by ruminal methanogens }\end{array}$ & {$[120][121]$} \\
\hline
\end{tabular}

This article is protected by copyright. All rights reserved. 


\begin{tabular}{|c|c|c|c|c|}
\hline \multicolumn{5}{|c|}{ Table 3. Comparison of recently reported enzymatic biocathodes } \\
\hline Catalyst & $\begin{array}{l}\text { Performance } \\
\text { compared to } \\
\text { 'Gold Standard' } \\
\text { Platinum catalyst }\end{array}$ & Lifespan & Cost & References \\
\hline $\begin{array}{l}\text { Bilirubin } \\
\text { Oxidase }\end{array}$ & Superior & $\begin{array}{l}\text { Short - large } \\
\text { scope for } \\
\text { improvement }\end{array}$ & $\begin{array}{l}\text { Crude enzyme low } \\
\text { Pure enzyme high }\end{array}$ & {$[53]$} \\
\hline Laccase & Superior & $\begin{array}{l}\text { Short - large } \\
\text { scope for } \\
\text { improvement }\end{array}$ & $\begin{array}{l}\text { Crude enzyme low } \\
\text { Pure enzyme high }\end{array}$ & [99] \\
\hline $\begin{array}{l}\text { Endogenous } \\
\text { Enzyme } \\
\text { Secretion }\end{array}$ & $\begin{array}{l}\text { Currently inferior } \\
\text { - scope to match, } \\
\text { if purity and } \\
\text { concentration are } \\
\text { improved }\end{array}$ & $\begin{array}{l}\text { Indefinite - as long } \\
\text { as enzyme } \\
\text { producing } \\
\text { microorganisms } \\
\text { have access to } \\
\text { nutrients and } \\
\text { retain plasmid }\end{array}$ & $\begin{array}{l}\text { High initial } \\
\text { investment in case } \\
\text { of GMO } \\
\text { Low cost for WT }\end{array}$ & [99], [102],[103] \\
\hline $\begin{array}{l}\text { Surface } \\
\text { Presented } \\
\text { Enzymes in } \\
\text { Yeast }\end{array}$ & $\begin{array}{l}\text { Currently inferior } \\
\text { - reduced by } \\
\text { yeast's } \\
\text { competition with } \\
\text { cathode for } \mathrm{O}_{2}\end{array}$ & $\begin{array}{l}\text { Indefinite - as } \\
\text { long as yeast have } \\
\text { access to nutrients }\end{array}$ & $\begin{array}{l}\text { High initial } \\
\text { investment in case } \\
\text { of GMO } \\
\text { Low cost for WT }\end{array}$ & $\begin{array}{l}{[104],[105],} \\
{[107]}\end{array}$ \\
\hline
\end{tabular}

This article is protected by copyright. All rights reserved. 


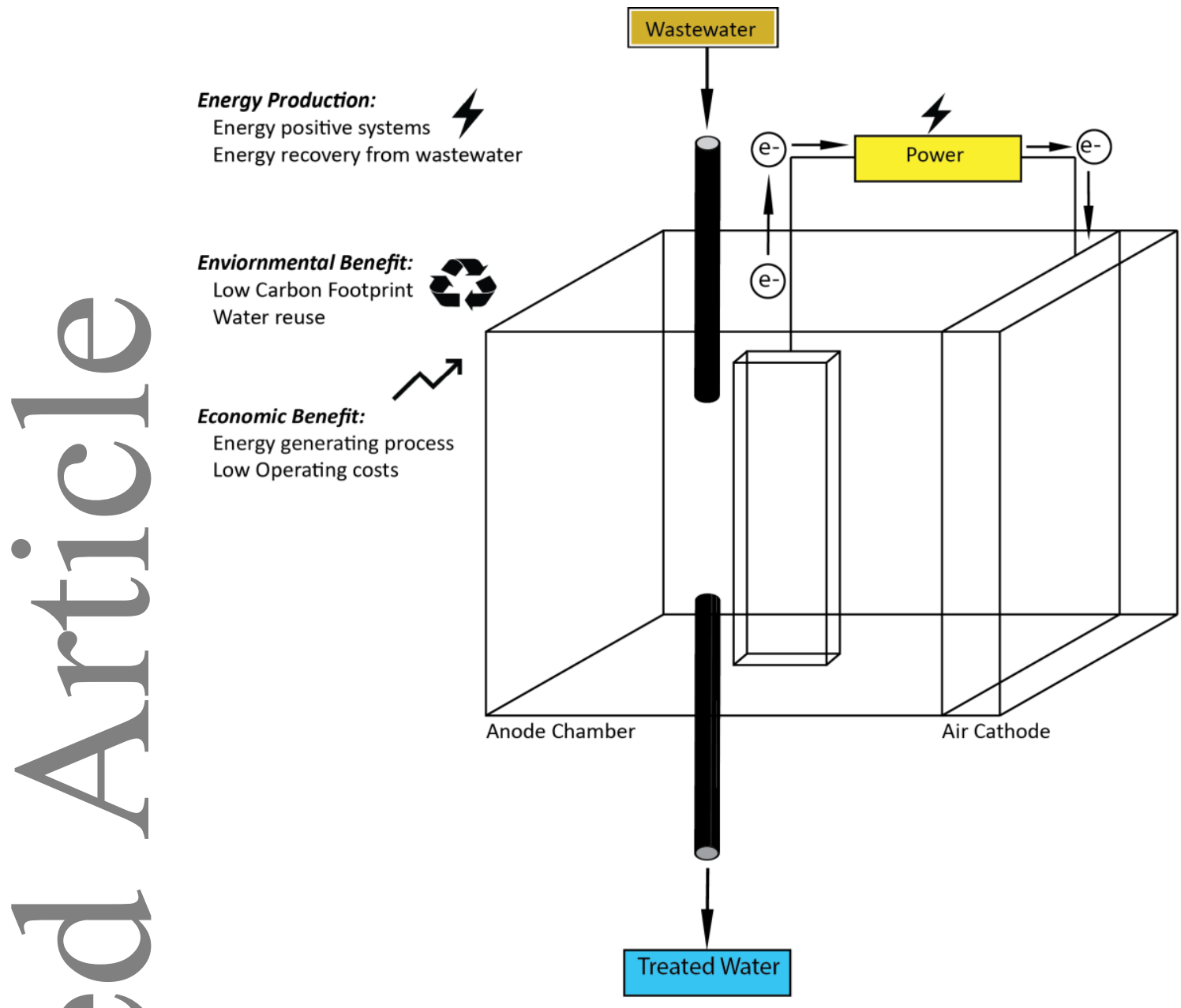

Figure 1: A generalised single-chamber microbial fuel cell wastewater treatment system, with some major advantages listed.

This article is protected by copyright. All rights reserved. 
